СHAPter $2 /$

\title{
Greek Myth as a Semiotic and Structural System and the Problem of Tragedy
}

In the infancy of society every author is necessarily a poet because language itself is poetry. . . . Every original language near to its source is in itself the chaos of a cyclic poem: the copiousness of lexicography and the distinctions of grammar are the works of a later age, and are merely the catalogue and the form of the creations of poetry.

-P. B. Shelley, "A Defence of Poetry"

\section{I}

The structuralist controversy of the seventies, as Marc-Eli Blanchard suggests, has gradually been replaced by a semiotic controversy. ${ }^{1}$ From the point of view of semiotics, culture depends on manipulating complex sign systems; and the activities of culture, in large part, consist of the continuous transformation and translation from one communicative system to another. Language obviously occupies a privileged place in the semiotics of culture, not only because of its unique communicative power but also because of its unique ability to reflect explicitly on the nature of the semiotic process and the interrelation of the various semiotic networks that make up the totality of a given culture. At the same time semioticians have

I thank Nancy Rubin for many helpful comments and suggestions. I gratefully acknowledge a fellowship from the John Simon Guggenheim Memorial Foundation (1981-82), during which this essay was put into final form.

I. Marc-Eli Blanchard, Description: Sign, Self, Desire. Critical Theory in the Wake of Semiotics (The Hague I980). 
called attention to the fact-hard to acknowledge for those of us trained as philologists - that language does not have an exclusive monopoly on signification. The question of the relations between verbal and nonverbal sign systems becomes particularly interesting and important in the study of myth. As a form of mythos, a spoken tale or account, myth is obviously inseparable from language, but it is, some would argue, at least partially independent of language or even transcends language. ${ }^{2}$

The study of myth is both important and difficult for semiotics because myth stands at an intersection of different sign systems. Myth comprises a system of symbols, verbal, visual, and religious. Each myth is built up of already existing symbols and forms and, like all narrative, reforms and reorganizes those symbols into its own structures. Myth, as Roland Barthes suggests, is a "second-order semiotic system," which creates its own language, its own system of relations between signifier and signified, from the primary significations of cultural values and narrative forms. ${ }^{3}$ At one level, myth provides a body of stories and symbols that validate cultural norms. A society's myths are the imaginative distillation of its descriptions and prescriptions about what life is and should be. We can easily think of Greek myths that warn about violating taboos or marrying within certain degrees of kinship or, more positively, set forth the ideal mode of behavior for husband or wife, son or daughter, old or young.

Viewed with an eye to structure rather than content, myths form a body of interrelated narratives that reveal an implicit system of logical relations. These relations become particularly striking when a large body of myths is examined at once, as Claude Lévi-Strauss has done for the Indians of the Amazon Basin. The totality of a corpus of myths may be read as a single text that possesses the internal coherence, autonomy, and coding processes of Barthes's second-order

2. See Albert Cook, Myth and Language (Bloomington, Ind. I980), Introduction and chaps. 2 and I I. For the question of narrative discourse in myth and other forms of discourse see also J.-P. Vernant, Mythe et société (Paris I974) 2 I $4 \mathrm{ff}$.

3. Roland Barthes, Mythologies, trans. A. Levers (London I972) I I $3 \mathrm{ff}$.; see also Terrence Hawkes, Structuralism and Semiotics (Berkeley and Los Angeles I973) I 3 Iff. Juri Lotman, The Structure of the Artistic Text, trans. R. Vroon, Michigan Slavic Contributions 7 (Ann Arbor I977) gff. speaks of "secondary modeling systems," and see also his remarks on "recoding," $35 \mathrm{ff}$. 
semiotic system. In reading the whole body of a society's myths in this way, we are constructing the "megatext" of its mythic material (I shall explain the term more fully later). This megatext is an artificial construct, necessarily invisible and unconscious to the society whose exemplary narratives and symbolic projections of what reality is are located within that system.

The first section of this essay attempts to show how Greek myth may be described in terms of a megatext, or in other words how the inherent systematicity of Greek myth operates in specific texts and narratives. Section II focuses on tragedy as a special form of mythical narration. Tragedy, I shall argue, simultaneously validates and disintegrates the mythic system both as a form of narrative representation and as a reflection of a coherent world order whose stable, hierarchical interrelation of parts is encoded into the myths.

Myth, though operating primarily through language, also shares common boundaries of content, formal organization, and expression with the visual arts, ritual, music, and in ancient Greece architecture also, for the plastic expressions of the myths frequently occur on the friezes and metopes of temples and other sacred buildings. Because of this overlap, no single brief definition of myth can encompass all its many functions and aspects. From a semiotic point of view, however, we may say that myth is a narrative structure whose sign- and symbol-systems are closely correlated with the central values of the culture, especially those values which express a supernatural validation, extension, or explanation of the cultural norms. Myth is also a more or less coherent system of symbols that express relationships between the human world and the forces of nature and the various forms of the unknown: the gods, the dead, the afterlife.

Greek myth is especially interesting from a semiotic point of view for two reasons. First, the presentation of myth in Greek literature shows a high degree of what we may call the metaliterary or metalingual consciousness. Even in Homer the poet is clearly conscious of shaping his work by structuring language and narrative elements. Within the mythic corpus the creative power of language, art, and poetry is itself often a subject of narrative: we may recall the pervasive details of weaving and crafting; the interest in the poet as an actor, a figure in the narrative (particularly in the Odyssey); the inclusion of comprehensive symbolic artifacts, such as the Shield of 
Achilles in the Iliad, 4 and the frequent representation of the heroic warrior himself as a bard, whether literally or metaphorically or, as in the Odyssey, both simultaneously; 5 and the magic of poet figures like Orpheus, Musaeus, Amphion, and Zethus. ${ }^{6}$

A conscious awareness of sign systems, furthermore, pervades early classical myth in its literary expression. In Aeschylus, for example, the devices on the shields of the seven warriors who attack and defend Thebes, the attention to the beacons in the Agamemnon as a coded form of communication apart from language, 7 the concern with names and naming as in the famous ode on the name of Helen $(A g$. $68 \mathrm{I}-98)$, the interest in omens and prophecies, and in Sophocles and Euripides the puns on names such as Oedipus and Pentheus-all are indications of an advanced, if not explicit, semiotic consciousness. 8 A t a later date this awareness of the signifying power of language, or metalingual consciousness, receives theoretical formulation in the work of some of the early Sophists, among them Protagoras, Prodicus, and Gorgias, who are among the first philosophers of language and literature in the West, and in their immediate successors, Cratylus and Democritus. The latter, the most systematic of the fifthcentury materialistic philosophers, speculated on whether language existed by convention (nomos) or by nature (physis), that is, as a secondary invention or as an instinctive capacity of man. ${ }^{9}$ This highly

4. See K. J. Atchity, Homer's Iliad: The Shield of Memory (Carbondale, Ill. I978). 5. E.g. Od. II.368 and 2I.405ff.; also Il. 9. I $86 \mathrm{ff}$. See Klaus Rüter, Odysseeinterpretation, ed. K. Matthiessen, Hypomnemata I9 (Göttingen I969) 237ff.; C. Segal, "Kleos and Its Ironies in the Odyssey," $A C 52$ (1983) 22-47.

6. See C. Segal, "The Magic of Orpheus and the Ambiguities of Language," Ramus 7 (1978) I 06-42, especially I I 4-2 I.

7. See J. J. Peradotto, "Cledonomancy in the Oresteia," AJP 90 (I969) I-2 I, and "The Omen of the Eagles and the Ethos of Agamemnon," Phoenix 23 (I969) 237-63; Froma Zeitlin, "Language, Structure and the Son of Oedipus in Aeschylus' Seven against Thebes," in Contemporary Literary Hermeneutics and Interpretation of Classical Texts, ed. Stephanus Kresic (Ottawa 198I) 235-52, and Under the Sign of the Shield: Semiotics and Aeschylus' Seven against Thebes (Rome I982); Pierre Vidal-Naquet, "The Shields of the Heroes," in J.-P. Vernant and Vidal-Naquet, Tragedy and Myth in Ancient Greece, trans. Janet Lloyd (Brighton, Sussex I98 I) I $29 \mathrm{ff}$.

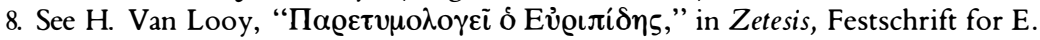
De Strijcker (Antwerp and Utrecht I973) 345-66; C. Segal, "Etymologies and Double Meanings in Euripides' Bacchae," Glotta 60 (I982) 8I-93; J. H. Quincey, "Etymologica," RhM Io6 (I963) I 42-48, on Aeschylus and Pindar.

9. E.g. Democritus D-K $68 \mathrm{~B} 9$ and $\mathrm{r} 25$. See in general U. von Wilamowitz- 
Greek Tragedy: Myth and Structure

sophisticated metalingual consciousness plays an important part in the later phase of Greek tragedy, especially the late works of Sophocles and Euripides; but it is, I believe, implicit in all of Greek literature.

The second reason for semiotic interest in Greek myth is that myth functions as a complex network of interrelated symbols, patterns, and structures that encode the values of the culture into an extensive and comprehensive system. The total corpus of myths, read synchronically, can be regarded as a megatext within which the specific literary narrations of particular myths (the Homeric epics, Hesiod's Theogony, the Homeric Hymns, the narrative portions of choral poetry, and tragedy) operate as subtexts, exploiting particular aspects of the megatext, commenting on it, and sometimes making explicit networks of interconnection implied but not openly stated in the megatext. By megatext I mean not merely the totality of themes or songs that the poets of an oral culture would have had available in their repertoires but also the network of more or less subconscious patterns, or deep structures, or undisplaced forms, which tales of a given type share with one another. ${ }^{10}$ The term thus includes the Greeks' own consciousness of the thematic affinities among the privileged narratives that we call myths (e.g., the perception of the common sequence of events in tales of the young hunter studied by Nancy Rubin and William Sale). It also includes the subconscious patterning from which these myths are generated, visible to us through comparative analysis of a large body of myths but not overtly perceived by the Greeks themselves as a pattern (e.g., the ambivalence surrounding the mature female figure studied by Slater, or the pharmakos pattern in the Oedipus myth pointed out by Vernant, or the initiation patterns in legends about the returning heroes of the Trojan War discussed by Bremmer). ${ }^{11}$

Moellendorff, Euripides, Herakles (Berlin 1907) on line 56; Felix Heinimann, Nomos und Physis (Basel I 945) I 56-62; W. K. C. Guthrie, A History of Greek Philosophy 3 (Cambridge I969) 204ff.

I0. On displaced and undisplaced narrative forms see Northrop Frye, The Secular Scripture: A Study of the Structure of Romance (Cambridge, Mass. 1976) $36 \mathrm{ff}$.

I I. See Nancy Rubin and William Sale, "Meleager and Odysseus: A Structural and Cultural Study of the Greek Hunting-Maturation Myth," Arethusa I6 (I983) I37-7I; Philip Slater, The Glory of Hera (Boston I 968) passim; J.-P. Vernant and Pierre Vidal- 
The megatext of Greek myth is remarkably coherent. It owes that coherence in part to the way that the literary forms in which all extant Greek mythic narrative occurs have already done some of the work of laying bare and developing the implicit logic of the system. Oral narrative in monumental epic, and particularly Homer and Hesiod (as Herodotus pointed out, Histories 2.53), further refined and regularized the megatext. ${ }^{12}$ Indeed, Homer seems to lay particular stress on the internal coherence of the mythic corpus by linking myths from different parts of the corpus to one another for illustration and paradigmatic analogy:13 the references to the Theban cycle, the tale of Meleager in Iliad 9, the songs of Demodocus in Odyssey 8, and the cosmogonic myths (whether or not overtly marked as such) in both epics. Even if we allow for the originality of an individual genius, Homer is probably developing a systematic coherence already present in the mythic material.

In Greek culture, in any case, the myths come down to us filtered through the nascent semiotic consciousness, or what I have called the metalingual consciousness, of the authors on whom we depend for the narratives of these myths. We have no other access to mythic material. The visual representation of the myths on painted vases and in sculpture presents exactly the same situation. Even the mythological compilations and handbooks of Apollodorus and the mythographers are not innocent of this literary restructuring, for they are themselves drawing upon literary or artistic versions of the myths. To use a linguistic analogy, analysis can reveal some aspects of the langue, the synchronic structure of myth as a megatext, beneath the parole of the individual works of verbal or visual art which have

Naquet, Mythe et tragédie (Paris I972) IOI-3 I (or Tragedy and Myth [note 7] 87-I I9); and Jan Bremmer, "Heroes, Rituals, and the Trojan War," SSR 2 (I978) 5-38.

I2. See Walter Burkert, Structure and History in Greek Mythology and Ritual, Sather Classical Lectures 47 (Berkeley and Los Angeles I979) I4 I. For indications of the mythic corpus prior to Homer, see T. B. L. Webster, From Mycenae to Homer, $2 \mathrm{~d}$ ed. (London 1964) chap. 6; also B. C. Dietrich, The Origins of Greek Religion (Berlin I974), with the bibliography. For some scholars, Hesiod already represents an intermediate stage between oral myth and the systematizing of written narrative: see Eric A. Havelock, The Greek Conception of Justice (Cambridge, Mass. I978) I93ff., and Vernant, Mythe et société (note 2) $208 \mathrm{ff}$.

I3. See M. M. Willcock, "Mythological Paradeigma in the Iliad," CQ I4 (I964) I 4 I-54; B. K. Braswell, "Mythological Innovation in the Iliad," CQ 2 I (I97I) I6-26. 
imposed their secondary aesthetic structure on mythic narrative, or to put it differently, have recoded these structures into their particular idiolect of artistic expression. 14

In the classical period, with which I am chiefly concerned, Greek myth operates with a set of more or less uniform symbols, culturally defined, whose syntagmatic relations are predominant. The paradigmatic axis remains overlaid by the logical coherence of the syntagmatic. The expression that these myths take in art and literature stays very close to naturalistic representation, wherein the paradigmatic relations are only implicit, rarely explicit. In the balance between the paradigmatic and the syntagmatic axes which operates in all narrative, Greek art forms privilege the syntagmatic axis. 15 The narrative or the visual depiction, that is to say, stresses temporal and spatial continuity and a well defined series of cause-effect relations among the parts. This logic of syntagmatic relations has, of course, dominated Western art and literature and until recently formed the basis of its naturalistic representation of the world, both in verbal and in visual expression. 16 The balance is just the reverse of the iconic form of, say, Byzantine art where, as Boris Uspensky shows in his semiotic study of the Russian icon, the paradigmatic relation forces itself through the syntagmatic. 17

The success of the Greeks in promoting the continuous frame of their syntagmatic axis is such that classicists have tended to accept that axis, the naturalistic surface of forward-moving plot, as the only legitimate object of study (how many titles like "Plot Coherence in $\mathrm{X}$ " or "Narrative Inconsistency in $\mathrm{Y}$ " recur in our bibliographies!). Only gradually and recently, partly as a result of structuralist and

I4. Some scholars prefer Noam Chomsky's terms competence and performance to Saussure's langue and parole, but the latter remain serviceable. For discussion see Victor Turner, "Symbolic Studies," Annual Review of Anthropology 4 (I975) I 49-50, and J. J. Peradotto, "Originality and Intentionality," in Arktouros: Hellenic Studies Presented to B. M. W. Knox, ed. G. W. Bowersock, W. Burkert, and M. C. J. Putnam (Berlin and New York 1979) 5-6.

I5. For a lucid account of syntagmatic and paradigmatic in a classical context see $\mathrm{J}$. J. Peradotto, "Odyssey 8.564-7I: Verisimilitude, Narrative Analysis, and Bricolage," Texas Studies in Language and Literature is (1974) 8 I $8 \mathrm{ff}$.

I6. For the bias toward realistic conventions of narrative see Frye (note ro) $44 \mathrm{ff}$. A propos of Shakespeare's Pericles he remarks (44): “The play shows us nothing at all about the relation of fiction to reality: what it shows us is that some conventions of storytelling are more obsessive than others."

17. Boris Uspensky, The Semiotics of the Russion Icon (Lisse 1976) chap. I. 
Greek Myth as a Semiotic and Structural System

semiotic analysis, have we begun to stress the paradigmatic level that operates through and beneath the syntagmatic axis. J.-P. Vernant's study of the Oedipus Tyrannus and Froma Zeitlin's of the Seven against Thebes are good examples of this recovery of the paradigmatic axis. 18 Reluctantly, we have acknowledged that metaphor, image, and symbol constitute meaning just as much as does the linear progression of the plot.

The special place given to the art of the fifth century B. C., partly as a result of historical and intellectual movements in the eighteenth and early nineteenth centuries (e.g., classicism), has also had its share in our collaboration with the Greeks in the assumption of the "naturalness" and inherently logical nature of the syntagmatic axis. Archaic art, however, gives a fuller role to the iconic aspect of the image and to the paradigmatic relations that accompany it. ${ }^{19}$ It relies more heavily than classical art on a system of relations that are not explained or clarified in the linear or spatial unfolding of the work but become intelligible only through a cross-section of many such works. In some early vase paintings, for example, the hieratic symbol of the goddess of animals, surrounded by her pair of heraldic lions, has been abstracted to a column with a scroll on either side.20 Or the apotropaic function of the Gorgon-mask in a fairly naturalistic representation of a human face gives way to the eyes alone, represented on the vase with no attempt at subordination into that syntagmatic order of lineaments which would integrate them into a clearly recognized total image of a human face.

I suggest two ways of approaching a semiotic analysis of Greek myth: first, through a reconstitution of its symbolic network as a

I 8. See above, note 7; Vernant and Vidal-Naquet, $M \gamma$ the et tragédie (note I I) Io I-3 I (or Tragedy and Myth [note 7] 87-I I9).

19. The shift of emphasis from classical to archaic art forms, which may be discerned, for example, in Nietzsche's influential Birth of Tragedy (1872), ushers in a new, "modern" phase of critical values: see M. S. Silk and J. P. Stern, Nietzsche on Tragedy (Cambridge 198I) 33-37.

20. In Max Hirmer and P. E. Arias, A History of Greek Vase Painting (London I 962), for example, compare the Boeotian "Potnia Theron" (plate I I) or the figure on the neck of the François Vase (plate 46, top) with the lions on the neck of the late geometric Cycladic amphora, color plate V. Cf. the suggestive remarks on the symbolic interchangeability of human form and architectural column by Guido von KaschnitzWeinberg, Die mittelmeerischen Grundlagen der antiken Kunst (Frankfurt a. M. I944) 22ff., with figs. I5-I6. 
whole; second, through an analysis of certain logical relations in a few characteristic myths.

To take a relatively simple instance of this network, the youth at the transitional point between adolescence and manhood is a recurrent figure in Greek myth: Theseus, Perseus, Telemachus, Orestes, Phaethon, Hippolytus, and Actaeon are familiar examples. Their importance reflects concern with the socialization of adolescent energies. These myths have been analyzed anthropologically in terms of rites of passage and psychologically in terms of dependency on a powerful maternal figure (Erich Neumann's "Great Mother").21 From a semiotic point of view, however, what is interesting is the process of coding which interrelates all of these myths as common parts of the megatext. In all or most of these myths the youth is a hunter (Hippolytus, Actaeon), or ends up in the wild (Pentheus) or as hunted victim (Orestes), or undertakes a journey from home into the unknown, monster-plagued wilderness (Telemachus, 'Theseus, Oedipus, Perseus). Structural analysis enables us to decode the form of sequential (diachronic) biographical narrative into a synchronic structure of polarities which underlies the cultural values, an opposition between nature and culture, wild and civilized, bestial and human. The figure of adult male warrior, citizen, and farmer occupies the civilized realm as the norm of cultural values, and the not fully socialized figures of adolescent youth, child, and unmarried woman occupy the opposite pole of the uncivilized or wild. Thus the myth of the young man cannot be viewed in isolation. It is homologous with the myths that treat the child as a beast or view the young girl as an unyoked heifer (an animal not yet fully brought into the realm of domesticated usefulness), or a faun, or a filly that has not yet been ridden. These relations, in turn, parallel the marginal political, religious, and military status of the adolescent figure. In other words,

2 I. Erich Neumann, The Origins and History of Consciousness, trans. R. F. C. Hull (Princeton 1954) chap. 2. For a "decoding" of these myths in terms of cultural, narrative, and historical patterns see P. Vidal-Naquet, "The Black Hunter and the Origin of the Athenian Ephebeia," in PCPS n.s. I4 (1968) 49-64; Joseph Fontenrose, Orion: The Myth of the Hunter and the Huntress, University of California Publications in Classical Studies 23 (Berkeley and Los Angeles 1980). For a good survey of modern approaches and cross-cultural comparisons see A. Brelich, Paides e Parthenoi, Incunabula Graeca 36 (Rome i 969) I 3-i i 2. 
the myths encode that marginality into a number of homologous narrative forms to express its various aspects in differing but parallel symbols: wilderness rather than city, virginity rather than sexual maturity, adherence to the mother rather than the father, wandering rather than stability, and so on.

Particularly interesting from a semiotic perspective is the way in which any one of these figures may serve as a paradigm for another. We are dealing here with a coded system of virtually interchangeable symbols. In the story of Pentheus as told by Euripides in the Bacchae, for instance, the young man undergoes a failed rite of passage: instead of defending the walls of his city as a stable, disciplined hoplite warrior and proving his rightful place within the city in a patrilinear inheritance, he is made female in his disguise as a female worshiper of the god of madness, brought outside the city walls into the wilderness of the mountains, treated as a hunted beast, defeated by women, reduced to the stage of infancy, and even symbolically devoured by his own mother. 22 Not only is there a systematic logical reversal of the positive paradigm of the megatext here, but there is a consciousness of the interrelated wholeness of that text through the example of Actaeon, cited no fewer than four times as a parallel to Pentheus. Likewise, the Odyssey repeatedly draws elaborate and explicit parallels between Telemachus, who proves his maturity by defending his right to his patrimony, and Orestes, who has defended his patrimony and reestablished the honor of the male line at $\mathrm{My}-$ cenae by killing his mother, Clytaemnestra, and her paramour, Aegisthus.

All these youthful figures on the threshold of manhood have a common structural relation that the poets regularly exploit. The parallels between them can be explicit and hortatory (anagogical) as in the Odyssey; more or less implicit, as in Aeschylus' Eumenides or Euripides' Hippolytus and Bacchae; or entirely implicit. The last type is perhaps the most interesting for semiotic analysis, for it reveals the operation of a subverbal pattern of narrative structures only.

In Sophocles' Trachiniae, for example, the poet is able to draw on the megatext in order to present the action of the play as suspended between two simultaneous and opposing paradigms, the myths of the

22. See C. Segal, Dionysiac Poetics and Euripides' Bacchae (Princeton I982) chap. 6. 
Odyssey and the myth of the Oresteia. We may present their relation to the action diagrammatically:

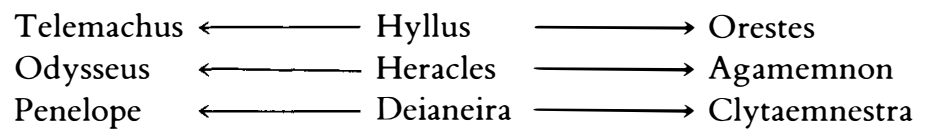

Deianeira begins as a Penelope-figure, the patiently waiting, faithful wife, but ends up a Clytaemnestra, the murderous wife who destroys her husband at his homecoming. Heracles seems an Odysseus, off in remote places in the execution of heroic deeds, but he returns an Agamemnon, a proud and violent man who has destroyed a city and brings back a captive princess as his prize with little regard for the sanctities of his house or his marriage. (Note that Odysseus leaves Nausicaa, a potential Cassandra or Iole, on Scheria and returns unaccompanied, his arrival marked by a meeting with the nonsexual, nonseductive virgin Athena, disguised, in fact, as a male.) Hyllus too is strung between the two sets of paradigms. He begins as Telemachus, going off in search of his father as the first step in leaving his mother and the female-dominated household. But he ends up playing the role of Orestes, having to choose between father and mother and in fact asked to collaborate in the killing of his mother in vengeance for his father.

Noteworthy here is that neither Telemachus nor Orestes is ever explicitly mentioned in the Trachiniae; nor are Agamemnon and Clytaemnestra, Odysseus and Penelope. The tragedian can count on the implicit systematicity of the mythic corpus as megatext. Or, to put it differently, he can expect that his audience will be able to reencode the relations of the characters of his play into the parallel and homologous configurations in the megatext, and he can count on both the interchangeability and the polysemicity of these figures in the megatext. Any individual mythic figure can function as the starting point for a whole nexus of logical relations and subtle modulations between paradigms.

To turn to another set of such relations, a large body of myths deal with sacrifice and especially with perverted or distorted sacrifice (e.g., the myths of Atreus and Thyestes or Agamemnon). These myths do not merely justify rituals or explain their origins, after the manner of so-called charter myths or etiological myths. They must be viewed as part of the same semiotic system, an intricate web of 
logical relations having to do with the hierarchical ordering of the world biologically (god, man, beast), spatially (Olympus, earth, underworld), eschatologically (immortal, mortal, dead), and through diet (ambrosia as the food of the gods, grain and the cooked and perishable flesh of animals for mortal men, raw food on which wild beasts live). In such a system an element such as ambrosia is not just a food but a symbol with multiple interconnections to other codes, most strikingly to the poles of mortality and immortality, since etymologically it is exactly cognate with immortal.23

The dynamics of the system, by which an individual mythic figure generates parallels with analogous forms of the same relation elsewhere in the megatext, can be seen from two myths where ambrosia is especially important, the story of Tithonus, husband of Eos, and the story of Ganymede, cupbearer of the gods on Olympus. These two myths are correlated as complementary paradigms to the godmortal union of Anchises and Aphrodite in the Homeric Hymn to Aphrodite. This early text tells the story of the siring of Aeneas from the union of mortal Anchises and the goddess of love. Both Tithonus and Ganymede are paradigms for mortal-immortal unions. Taken together with the story of Anchises and Aphrodite, they give that model a further level of meaning and thereby illustrate the overdetermination or redundancy characteristic of the encoding of cultural values within this megatext. To put it differently, they encode the message of the subtext (the union of immortal and mortal) into several other sets of terms.

In the narrative of the Hymn the interlocking parallels between Ganymede and Zeus, Tithonus and Eos, and Anchises and Aphrodite validate the symmetry between men's separation from the gods by age and death and their approximation to the gods through beauty and the power of eros (a point that Plato will develop in a very different way some three centuries later). Ganymede reaches Olympus and enjoys an eternity of unchanging youth. Tithonus gains an immortality of increasing old age; he is placed not on Olympus but "by Ocean's streams at the limits of earth" (227). Anchises meets his immortal lover, Aphrodite, on the earth, Mount Ida. He remains mortal but obtains the equivalent of immortality allowed to mortals,

23. For a systematic exposition of these homologies, see Marcel Detienne, Les jardins d'Adonis (Paris 1972). 
a son who will perpetuate his race from generation to generation, ruling over the Trojans (196-99). 24

The graduation in the biological code from immortal youth to mortality, heterosexual reproduction, and old age is also present in the parallel codes of space and food. Ganymede, on Olympus, pours out the gods' immortalizing beverage, "rosy nectar from a golden jar" (206). Tithonus, who gains immortality but not eternal youth, has as his diet an anomalous mixture of "both grain and ambrosia" (sitōi t' ambrosiēi te, 232). His abode is neither earth nor Olympus but a place distanced from both, "Ocean's streams at the limits of earth" (226). The anomalous plus in the dietary code (both grain and ambrosia) is symmetrical with the minus implicit in the spatial code (neither earth nor Olympus).

A similar spatial anomaly characterizes the offspring of the union between mortal Anchises and immortal Aphrodite. As the heir to a mortal patrimony, Anchises and his descendants will rule over a city of men. But as the child of a goddess, conceived not in a civilized house but in a shepherd's steading on the wild mountainside, Aeneas spends his first years of life in the forest, between city and wild, nurtured by Nymphs who live on earth but eat "immortal food" (ambroton eidar) and have their long life-span (260) measured by the life of trees in the forest (264-72). Mediating between gods and men as between passionate erotic union and incorporation in regularized civic life, the Nymphs "follow neither mortals nor immortals" (259) but have as their sexual partners the silenoi (262), who combine the features of gods and beasts, and Hermes, the god of mediation between gods and mortals, Olympus and Hades. Aphrodite's union with Anchises hovers ambiguously between the pure lust of seduction and the sanctions of marriage (cf. I I 7-42, I 50). Luring him by talk of marriage, she makes even legitimate union serve her end of seduction. So too the child born of this union hovers ambiguously between recognition by his parents and concealment by his parents. The mother refuses to allow public recognition of her union with the father, Anchises, and yet like a true mother provides for the child's nurture (trophe: $\mathrm{cf}$. 273) and describes prophetically his early years of

24. For further details, see C. Segal, "The Homeric Hymn to Aphrodite: A Structuralist Approach," CW 67 (1973/4) 205-12, and Tragedy and Civilization: An Interpretation of Sophocles, Martin Classical Lectures 26 (Cambridge, Mass. I982) 22-24. 
dependency on her maternal surrogates (273-79). Spatial, sexual, marital, dietary, and biological codes are all correlated in homologies that create a concrete, nonabstract systematicity organizing both natural and supernatural worlds.

The mythical structures of Pindar's Odes lend themselves to similar analysis. In the first Olympian the love relations of GanymedeZeus and Pelops-Poseidon in the sexual code are symmetrical with the god-mortal relations violated in the dietary code. Ganymede's successful attainment of Olympus parallels Pelops' dismissal from Olympus. The symmetrical mediations between god and mortal effected by both Ganymede and Pelops (though to different degrees) contrast with the failed mediation of Tantalus. Ganymede is a mortal youth taken up to Olympus by the gods. Pelops is sent from Olympus down to earth and later, allowed to reach the gods through the mortal mediatory forms of eros, ritual, and heroic honors. But Tantalus is sent from Olympus to Hades, beneath the earth, for attempting to bestow the gods' nectar upon his mortal companions. This violation of the god-man boundary in the dietary code is correlated also with the other crime to which the ode alludes, Tantalus' serving of his son Pelops as meat to the gods, an act whereby they would be reduced to the subhuman level of cannibals feasting on human flesh (Ol. I.48-54). Stealing and distributing to men the divine prerogative of the immortalizing liquid (Ol. I.55-67), Tantalus evokes another mediating figure in the megatext, the arch-mediator Prometheus (cf. Hesiod, Theogony $535 \mathrm{ff}$.), whose mixture of theft and generosity also involves the establishment of boundaries and passages between gods and men. Pindar's dense interweaving of paradigmatic analogies both uses and exemplifies the generative order contained in the megatext of these myths. He correlates the aesthetic and moral order of truth, poetry, and art with the sexual, dietary, and spatial order in the proper relations between gods and mortals.

In the first Pythian Ode that correlation of poetic, spatial, and moral order is made visually concrete in the image of Mount Aetna as a mythical locus of coinciding opposites, land and sea, fire and water, light and darkness, gentleness and power (cf. Pyth. I. I9-26).25 Con-

25. On Pythian I see Gilbert Norwood, Pindar, Sather Classical Lectures I9 (Berkeley and Los Angeles I945) IoI-5; S. D. Skulsky, "Pollōn peirata syntanysais: Language and Meaning in Pythian I," CP 70 (I975) 8-3 I. 
stituted as a mythic place, it is a "heavenly column," kiōn ourania (Igb), a form of the familiar cosmic pillar or axis mundi, holding the monster Typhos down under the earth but also extending upward from Hades through the mortal world of middle earth to Olympus. 26 Here Apollo's golden lyre, "beginning of radiance" (2a), creates song as a unifying symbol of divine order among men. Drawing probably on the Hesiodic depiction of Typhos as a creature of confused and dissonant voices (Theogony 830-35), 27 Pindar sets up an elaborate correlation of cosmic and musical order whose validation and present realization are the musical performance of the Ode itself. In what we may call an auditory or acoustic code, harmony reigns on Olympus through the "beginning of radiance," emanating from A pollo's golden lyre to the voice of the singers and the steps of the dancers (I-4). On earth the song of the poet, Pindar himself, contrasts the praise of lawful rulers with the just blame of bad kings such as Phalaris, who tortured his victims by making them roar in a bull of bronze which he had heated by fire (94-98). In the natural order the heavenly column of Aetna has its own cacophonous roar as it sends its fiery streams and rocks crashing down into the sea, a sound appropriate to the monster that it keeps down in Tartarus (I5, 20-24) but a source of wonder to those who see and hear it (26), for presumably they have been taught through the ode's ordering of the meaning of sounds to perceive the moral coherence behind such a monster and prodigy (teras, 26).

Pindar's elaborate correlation of song with the hierarchical cosmic order brings the poet's very act of artistic creation into the mythic structure: the frame is itself included in the content, the sender in the message. The poet thereby calls attention to his own role as a maker of hierarchies. He consciously draws his own aesthetic ordering of the world into parallelism with the cosmic ordering of Zeus, just as his lyre, the earthly and specific manifestation of Apollo's golden lyre, brings to mortal men the order-bringing, beauty-creating

26. On the cosmic pillar see Mircea Eliade, Patterns in Comparative Religion (New York 1958) 265ff.; on its place in Pythian I see Segal, Tragedy and Civilization (note 24) 22. In Aeschylus, PV 363-69, too, the monster's subjection to Zeus' order spans the "roots" and "highest crown" of Aetna.

27. A. von Mess, "Der Typhonmythus bei Pindar und Aeschylus," RhM 56 (I 90 I) I67-74 notes the Hesiodic parallels but is not interested in their implications. See J.-P. Vernant and Marcel Detienne, Les ruses de l'intelligence (Paris I974) 9of., I I $5 f$. 
power of the divine lyre on Olympus and makes the festal celebration of the moment transparent to the eternally reenacted harmony among the gods (cf. 97f. and Iff.).

Here a strong caveat is necessary. To separate the logical armature of the myth from its function in the literary work is to risk giving us a thin and partial reading of the text, the skeleton rather than the living flesh. A full analysis of the Homeric Hymn to Aphrodite, for example, would also demand our saying something about the play of deception which forms the essential nature of the love goddess as she appears to mortals and acts among mortals. We should say something about the way in which the constellation of lies, mountains, wild beasts, and seduction or rape not only forms a part of the cultural codes dealing with marriage and civic life but also enters into the language of the poem and creates Aphrodite's characteristic tone of playfulness. We should consider how the seductiveness and artful wiles of the goddess are also the seductiveness and artfulness of the poem itself, how the goddess' skillful telling of tales parallels the poet's skillful telling of tales: both use a mixture of truth and deception to accomplish their ends and to make of the passing pleasure of the moment something that, perhaps unintentionally, endures within the city and among its descendants. We should also have to pay attention to how these matters impinge upon the formulaic language of early hexameter poetry. We should study the poet's use of and modification of the formulaic attributes and traditional roles of the goddess of love as she appears in her various manifestations in the culture and in earlier poetry, an area where work by Gregory Nagy and Paul Friedrich has made important contributions. 28

\section{II}

Greek tragedy is a peculiar form of the megatext, the extended text of Greek myth regarded as a unified corpus. It is simultaneously a commentary on the megatext of the mythic system and the final text of the system, simultaneously the culmination of the system and its dissolution. Tragedy, like epic, correlates paradigms from different

28. Gregory Nagy, "Phaethon, Sappho, Phaon and the White Rock of Leukas," HSCP 77 (1973) I 37-78; Paul Friedrich, The Meaning of Aphrodite (Chicago 1978). 
parts of the text in the way we have examined in the first part of this essay. Tragedy specializes in a complicated running together of homologous codes through metaphor and parallel narrative structures (we need think only of the Oresteia). More distinctively still, it plays with the logic of the system by working through elaborate reversals of the expected patterns. It prefaces the dynamic syntax of the archaic myths, as it were, with a negative sign. Its semiotic function in the culture may be compared with the concept of the carnivalesque in the work of Bakhtin, Kristeva, and Toporov or with the liminal and liminoid in work of Victor Turner. ${ }^{29}$

The god of the carnivalesque in Greek culture is also the god of tragedy and comedy: Dionysus. The peculiar relation of Greek tragedy to its mythical material has undoubtedly much to do with the god at whose festival and under whose aegis the plays were performed. Greek tragedy, one might say, places the megatext of myth in the liminal, carnivalesque space occupied by its god. The mediations of opposites which occur in the myths are collapsed together in multiple paradoxes and ironies in the realm of the god whose very nature is a constellation of coexisting contradictions: male and female, young and adult, chthonic and Olympian, human and bestial, Asian and Greek, creative and destructive. In tragedy the firm polarities and the clear expression of values in the social order are dissolved in ambiguity, complex inversions, and conflicts. The basic moral terms of civilized life become fluid and uncertain or tense with contradictions: wisdom and nature in the Bacchae, justice in the Oresteia or Antigone, knowledge in the Oedipus Tyrannus, purity in the Hippolytus, and so on.

One reason for this peculiar relation of Greek tragedy to the megatext of myth is the fact that tragedy itself seems to arise when social, political, and moral systems are in crisis or at a crossroads. At such junctures not only are value systems in flux but so, necessarily, are the modes of discourse that convey, describe, and encode those value systems. Language and the narrative forms dependent on language

29. See M. Bakhtin, Rabelais and His World, trans. Helene Iswolsky (Cambridge, Mass. I968); Julia Kristeva, Sēmeiōtikē: Recherches pour une sémanalyse (I969; Paris I 978) 99ff.; V. N. Toponov, "On Dostoevsky's Poetics and Archaic Patterns of Mythical Thought," trans. S. Knight, New Literary History 9 (I978) 333-52; JeanClaude Carrière, Le carnaval et la politique (Paris I979) 29ff., I 27ff.; Victor Turner, The Forest of Symbols (Ithaca I973) and Dramas, Fields, and Metaphors (Ithaca I974). 
inevitably participate in the crisis and the transition. As Timothy Reiss comments, "In Western history tragedy seems to have appeared at moments that, retrospectively, are marked by a kind of "hole' in the passage from one dominant discourse to another." 30 The seventy-year period (just two generations) spanned by extant Greek tragedy, which represents its mature creative phase, is clearly such a moment. The passage from one mode of social discourse to another includes the development of a language of conceptual thought, the languages of history and philosophy which the Greeks shaped for the rest of Western culture, and also a new narrative language of myth: tragedy.

Tragedy pulls the verbal ordering of language and the narrative ordering of myth in two different directions simultaneously: it validates, even if covertly, the established social, political, and religious values of the community, and it also enacts and releases the tensions within and among those values. Because of this double pull inherent in the critical and transitional nature of the mythic discourse in tragedy, it is possible to have a Marxist reading of Greek tragedy as the justification of the Establishment, like that of Peter Rose, and a more deconstructive reading of tragedy as reflecting breaches in the Establishment, like that of Jean-Pierre Vernant. 31

There is another factor in this transitional moment of Greek tragedy: tragedy develops in Greece at the point of intersection between oral and literate modes of narration and representation. Although writing existed in Greece in early times, earlier narration was primarily oral and audience-controlled. ${ }^{32}$ With tragedy, I believe, the role of writing becomes decisive in composition, for tragedy implies a written text, necessary to organize its dense, compact, multimedia

30. T. J. Reiss, Tragedy and Truth (New Haven I980) 284.

3I. Peter W. Rose, "A Dialectical View of Greek Tragic Form," Radical History Review I 8 (1978) 77-94; Vernant and Vidal-Naquet, Mythe et tragédie (note I I) I3-I 7, 2I-4O and Mythe et société (note 2) $205 \mathrm{ff}$. On the danger of viewing Greek tragedy as reflecting the ideas and values of a ruling class or dominant elite see S. Said, "Travaux récents sur la poésie grecque, (1960-80)," Information Littéraire 33 (I98I) 73. From a different point of view, it is possible that tragedy can be viewed in this double perspective because of its own never fully resolved tension between a wisdom of limits (sōphrosyne $)$ and an admiration for the unlimited aspirations of heroism: see A. Terzakis, Homage to the Tragic Muse, trans. A. Anagnostopoulos (Boston I978) I 89.

32. See Havelock (note I2) passim; Cook (note 2) 6ff.; Vernant, Mythe et société (note 2) 196-200. 
performance (dance, music, dialogue, recitation, etc.). Indeed, it is possible that the increasing importance of writing in the still largely oral culture of the early fif th century B.C. may have been one of the determinants in the origin of tragedy. The intersection of a literate and an oral culture results in the crossing between two semantic systems and a resultant complexity in the nature of mythic representation.

By the very fact of writing - and I have in mind also écriture in Jacques Derrida's sense-the poet of a hitherto oral culture is implicated in a system of abstractions which poses a barrier between his text and the univocal "truth" of an oral performance. Where the oral poet speaks as a voice of tradition and gives assurance of the validity of that tradition by his authoritative presence as the visible and present speaker or singer, the author of the oral performance of tragedy is absent, hidden behind his text. There is no single voice of truth. Instead, there is a plurality of voices, each with its claim to truth, justice, right, and piety; and no authoritative voice can pronounce unambiguously for any one of these voices, not even the chorus.

As dramatic performance, tragedy represents myth in its most solid, concrete, three-dimensional form, enacted on the stage before us. Yet at every moment there is a potential division between this surface tangibility and the abyss of illusion, appearances, deception. Tragedy presents a world characterized by a perpetual tension between deceptive surface and hidden truth, between appearance and reality. Poised between full representation and self-conscious fictionality, tragedy simultaneously culminates and dissolves the semiotic system behind the mythical material it uses.

This division between a surface world of illusion and a truth that lies beneath rests in part on the crossing between the two sign systems in its background, a verbal and a visual, a hidden text of written signs and a public, open, oral performance. The poet himself is operating in two different semantic systems, two different modes of communication, one (the oral) involving a social transaction of participation and exchange and the other (written) involving the abstractive distancing of écriture. "Writing is the grand symbol of the far," wrote Oswald Spengler. 33 Hence the representation of myth in tragLiteracy," in Goody, ed., Literacy in Traditional Societies (Cambridge I968) 55. 
edy hovers between distance and closeness at the same time. ${ }^{34}$ In the Trachiniae, for example, Sophocles brings on the stage a woman endowed with the civilized sensibilities of fifth-century Athens, someone whom the audience would have no trouble identifying as a contemporary. Yet she lives in a world where river-gods, Hydras, and Centaurs, the primordial monsters subdued by Heracles, are still recent and fresh.

Sophocles' Oedipus Tyrannus is simultaneously the most powerful instance of tragedy's divided world of appearance and reality, illusion and truth, and also the most elaborate example of tragedy's inversions of the coded systems in the megatext of Greek myths. It involves not only the reversal of king and scapegoat, as Vernant has pointed out, but a kind of rite of passage in reverse. 35 The king, recovering the origins of his life, finds his place not within the palace as the legitimate king's son-the usual pattern for the foundling hero, Theseus, Perseus, Cyrus, Ion-but in the wilderness as the polluted murderer, parricide, and incestuous husband of his mother, the total negation of the ordering power that should attach to the role of sacred kingship. These reversals are correlated with complex reversals in the nature of language and syntax, including the interchangeability of divine oracle and bestial shrieking of the monstrous Sphinx and the intricate double meanings of riddling speech in the celebrated tragic irony of Sophocles.

The Oedipus' self-consciousness about the logical patterning and its reversibility inherent in the syntax of language is paralleled by an analogous self-consciousness of reversibility in the syntax of the narrative structure, which Freud extrapolated as a universal life-plot of the human condition. 36 The coincidences that seem to guide the plot, accidentally, to its necessary conclusion also image the "coincidences," the coming together of disparate elements (syntychia) through which the poet shapes his work, interweaves and interconnects the separate elements of the narrative, the isolated incidents,

34. For a somewhat different view of this relation of closeness and distance in the relation of tragedy to myth, see Vernant, Mythe et société (note 2) 205f.; also Wolfgang Rösler, "Die Entdeckung der Fiktionalität in der Antike," Poetica I 2 (I980) 3 I $2 f f$. For a fuller discussion of these questions in relation to tragedy and literature, see C. Segal, Tragédie, oralité, écriture," Poétique so (1982) I 3 I-54 and "Greek Tragedy: Writing, Truth, and the Representation of the Self" in this volume.

35. Vernant, Mythe et tragédie (note I I) I I $7 \mathrm{ff}$.

36. Peter Brooks, "Freud's Masterplot," Yale French Studies 55/56 (1977) 280-300. 
Greek Tragedy: Myth and Structure

into a unified design. In the story of Oedipus, then, Sophocles projects upon heroic myth the syntax of tragedy, the coincidental coming together of accidents into a fully bound and integrated form that conveys a sense of necessity and inevitability. Here again tragedy constitutes at the same time both the fullest exemplification of the interlocking system of the megatext of myth and the deepest questioning of its coherence.

The very subject of the Oedipus Tyrannus is polysemicity. Few works of classical literature pay so much attention to their own semiotic system. The Oedipus Tyrannus pursues the logic of its inversions with the inexorability that Aristotle, founder of logical systematization, could never admire enough. Like the Bacchae, which it resembles in this conscious exploitation of logical reversal, it treats kinship as a system of logical relation and logical relation as a form of kinship. It explores the sexual roots of knowledge, the sexualization of knowledge, and the intellectualization of sexuality. Oedipus' search for himself is both man's emotional needs to grasp origins and man's intellectual need for orientation in the otherness of the world through such systems of relational logic as kinship. Confusion in the generational code (incest) is parallel to confusion in the linguistic code (riddle and oracle coming together, the multiple ambiguities of Oedipus' name and its origins as oidi-pous [swell-foot], oida-pous [know-foot], oida-pou [know-where], oi-dipous [alas, two-footed]). Incestuous marriage, a denial of the father, denies the hierarchizing and differentiating processes that operate both in language and in the social order to create personal identity and personal responsibility. Brought back to his origins by replacing his father, "sowing where he was sown," Oedipus questions the whole enterprise of culture, in which men mark the otherness of the phenomenal world and separate themselves from the nameless, random life of nature.

At the center of a semiotic system that is both too full and yet always threatening to disintegrate into emptiness, Oedipus is a constellation of opposites where the ambiguity of the individual's primal word, his name, implicates the entire denotational, differentiating system of language itself. 37 As a focal point for the equivalence of the

37. See Segal, Tragedy and Civilization (note 24) 24I-44; also C. Segal, "The Music of the Sphinx: The Problem of Language in Oedipus Tyrannus," in Kresic (note 7) I 5 I -63 . 
codes (familial, sexual, cognitional, biological, spatial, ritual), the myth exhibits and explores its own polysemicity with particular transparency; concurrently it explores its own a-semicity, the precariousness of signification, and the possibility that language may point to meaninglessness or deceive by the false appearances of meaning.

It is partly for this reason that Oedipus can be and has been interpreted with equal validity in so many different systems: psychoanalytical, linguistic, political, historical, religious, structuralist. The very problem of his existence, as posed in the myth is the problem of language: language crystallizes self and world into static forms, yet these forms have the changing aspect of things always in flux. Oedipus himself can be defined by his name only when the play has taken us through a powerful and painful experience that reveals the deceptiveness of language as an interpreter of reality and as a mediator between apparently steady surface and ever-shifting depths, between truth and appearance. Myths like this, which reflect (literally "bend back") upon themselves, on their own narrative syntax and its reversibility, seem to have the remarkable quality of deconstructing themselves. Certain myths, at least-I would put here those of Oedipus and Pentheus-reveal and explore the mechanisms for the deconstruction of the system of myth and the system of language out of which they themselves grow. The simultaneous use and questioning of these systems constitute perhaps the most distinctive feature of the recasting of myth in tragedy, carried to its furthest point in the Oedipus Tyrannus.

The Tyrannus shows how tragedy, as a secondary elaboration of myth, can tell its story while deliberately calling into question one of the most fundamental elements of mythic narration, the representation of time. Sophocles' play virtually deconstructs the myth by revealing the illusoriness of temporal progression in the story. The forward movement of the hero, driven like the audience by a curiosity both intellectual and sexual, both public and intimate, takes a path that is linear (because it marks an advance into the future) and simultaneously circular (because it reveals the present only as a repetition of the past, gripped at every point by the domination of past events that it cannot transcend). The push toward solution and closure becomes, at every point, an increasingly intense involvement in origins, opening wider gaps and larger spaces of the past. Each of 
the hero's conquests in the forward movement of his life, like each movement of the plot to a new episode, is only a clearer revelation of a hidden past, secrets of birth that prove more elusive the closer he gets. When Oedipus recovers his city and his mother by ignorantly solving the riddle of the Sphinx, he is blind to the real truth of himself. Beneath his alien status as victor and foreign husband he conceals the truth of his origins as legitimate son and heir. The remote past, with the blood ties that should assure him an intimate place in both house and city, cancels out the present, in which he possesses wife and kingdom after fulfilling the role of the young conquering hero (like Perseus or Theseus) who arrives from a distant land.

As Oedipus uncovers his hidden origins, so the tale of the birth of a child is also the discovery of a hushed attempt to murder a child. 38 The discovery of a father is also the discovery of killing a father. Finding his mother becomes the finding of himself as the husband of his mother, father of her children. Each discovery of origins opens upon something that must be immediately closed; the recovery of lost knowledge demands a closing up and concealment of that knowledge. Oedipus becomes the reader of a tale who discovers at its end that he is the missing piece which alone can bring the tale to its conclusion. Yet only the delay, by refusal of that discovery (a refusal that sometimes seems blind and perverse), allows the tale to unf old at all. 39

At the peripety, blinding himself with the brooches that he takes from Jocasta's robe, Oedipus reenacts the unraveling and unconcealing that pull every forward progress back to dark origins. His act of self-blinding brings with it the implication of baring (again) his mother's body, but now it gives him an inner vision that previously he had lacked. This penetration, by both feet and eyes, to places that should have remained hidden from him reveals to him the truth of his equivocal status as both the insider and the outsider, and it also

38. Shoshana Felman, "Turning the Screw of Interpretation," Yale French Studies 55/56 (1977) I6Iff. quotes an interesting passage from Serge Leclair, On tue un en fant (Paris I975): “Insupportable est la mort de l'enfant: elle réalise le plus secret et le plus profond de nos voeux. . .."

39. Felman (note 38) i75 has some interesting remarks on the parallelism of the Oedipus Tyrannus as a detective story and Henry James's The Turn of the Screw. 
reveals the transgressive status of his amgibuously legitimate place within the house and within the city. 40

The paradoxes surrounding the hero's discoveries parallel the paradoxes surrounding the kind of truth that the tragic poet reveals: this is a truth that intertwines darkness and clarity in our knowledge of ourselves and our place in the world. Spinning a web of pleasant deceptions, apatai in Gorgias' sense ( 82 B 23 D-K), the tragic poet reveals behind the delightful surface, the terpsis or hedone, of myth the ugly, painful, or shameful things that we know but cannot or will not speak. In the Tyrannus both the hero in his life story and language in the permutations that it undergoes in the course of the play have their pathe $\bar{e}$, their sufferings. In both an ultimately sexual mechanism of allure and seduction, the curiosity to see and experience, is transformed into the recognition of a horror that is simultaneously repulsive and fascinating. With the hero we, the audience, are drawn on in increasing desire to see and to know, even as we recognize more and more certainly that there will be pain, not pleasure, in what we will see. Uncovering the body of Jocasta in the intimate inner chambers of the palace near the end is the prelude not to a night of nuptial pleasure but to a perpetual night of guilty, tormenting knowledge.

In the Bacchae, as in the Oedipus, tragedy emerges as the form able to encompass its own contradiction, able to hold a delicate counterpoise between the creative and destructive energies of life and the centripetal and centrifugal forces of all (mythical) narrative. The god of tragedy asks the protagonist of the Bacchae, also deluded by appearances and fascinated by secrets that a mother would keep concealed, "Would you then see with pleasure what is bitter to you?"

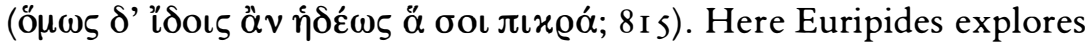
not only the systematic inversions made possible by the reversible syntax of the myth of Pentheus-shifts of active to passive, god to beast, highest to lowest, and so on-but also the relation of these reversals to the form that myth assumes in tragedy, that is, myth in the liminal, carnivalesque space of Dionysus.

The structure here is not a static antithesis but a tensely maintained

40. See John Hay, Oedipus Tyrannus: Lame Knowledge and the Homosporic Womb (Washington, D.C. I978) I04ff., I I9, I25; P. Pucci, "On the 'Eye' and the 'Phallos' and Other Permutabilities in Oedipus Rex," in Arktouros (note I4) I 30-33. 
harmony of opposites like that described in the celebrated fragment of Heraclitus (22 B 5I D-K): “They do not understand how being drawn apart from itself it agress with itself; a back-stretched harmonious fitting, as of a bow and lyre." The inner dynamics of the play show the capacity of the aesthetic form to absorb the destructiveness of the contents and the power of those contents to call into question and to disturb the beauty of the aesthetic form.

The Bacchae maintains this "back-stretched harmony" between the life-giving and the life-destroying power in Dionysus and the myths about Dionysus. There is a just and an unjust Pentheus, a just and an unjust Dionysus, a terrible and a gentle god, a lyrically mystical and a savagely murderous band (thiasos) of bacchants, a play that calls to the remote beauty of ecstatic worship of the life energies in the world and in ourselves and a play that makes us recoil with revulsion from the release of those energies. Euripides' tragic art makes both sides visible in their simultaneity, complementarity, and inseparability.

The play, by its very existence, marks the place where the destructive side of the Dionysiac energies of both god and storyteller have been overcome by the creative, the place where those energies have resisted desublimation and have been transformed into implements of civilization, into a token of personal reflection on the god and his rites. Coming at the end of the creative phase of Greek tragedy, the Bacchae reflects on the origin and nature of tragedy, on the point where art separates from ritual. The Bacchae also reflects on the destructiveness of the rite and dramatizes the emergence of self-conscious suffering and remorse out of group participation in the Dionysiac omophagy, the emergence of the individual from the group, and with that the emergence of tragedy from myth.

The vicarious representation of the Dionysiac ritual within the city limits at the Greater Dionysia replaces the celebration of the rites in the ecstatic thiasos on Cithaeron. Were those rites celebrated with full exuberance on the mountain and in the forest, without resistance, without reflection or hesitation, there would be no tragedy, perhaps no civilization. In the participation in the rites of the god in the oreibasia, the nocturnal revel on the mountain, there is no residue; everything is used up, joyously, in the moment of fusion with the god and in participation in nature's vital energies. In the performance of the rite in its symbolic and vicarious form in the theater of Dionysus, there remains the tragedy, which survives for future ages to 
ponder. In this celebration the participants sit immobile in their seats; and the action is entirely mental and inward, a complex, many-sided reflection on the rites that were or might be performed with the fullest, most energetic action on the mountains outside.

Tragedy is a form of myth which not only uses, illustrates, and interweaves the codes but also reflects on the logic implicit in the whole mythical system. In the Bacchae, Euripides has tragedy act out, in the visual form of dramatic representation, its own illusion-creating processes of masking, robing, and fiction making. The great scene where Dionysus, god of dramatic illusion as well as of wine, madness, and religious ecstasy, dresses the young king as a Maenad on the stage, visually enacts that process of fictional representation which the poet practices. The scene mirrors back to the audience their own willingness to endow an actor on the stage with the personage of a mythical being merely by virtue of the mask and robes with which the poet clothes him.

At the end of the Bacchae, Agave enters in her madness carrying the bloody head of Pentheus. Cadmus asks, "Whose prosoppon do you carry in arms?" (I277). His word prosōpon can mean "face" or "visage," but it can also mean "mask." It calls attention to the illusionistic process of the play itself, the use of masks to represent faces. It also marks a certain progression in the mimetic representation of the fiction being acted out on the stage before us. There is the face of Pentheus, which is really a mask (the double meaning of prosōpon), over which Dionysus has placed the wig and cap of a Maenad, in which Agave sees the head of a savage lion- "Do you see that cloud that's almost in shape like a camel?-By the mass, and it's like a camel indeed.-Methinks it's like a weasel.-It is back'd like a weasel.-Or like a whale?-Very like a whale" (Hamlet III.iii.393ff.). After playing a number of mutually contradictory roles-king and scapegoat, hunter and hunted, antagonist of the god and sacrificed victim-surrogate of the god, authoritarian monarch and ambiguously female bacchant-Pentheus is finally reduced to being an empty mask, carried by his mother who thinks that she is carrying the head of a lion.

Tragedy, then, develops the deconstructive potential inherent, perhaps, in all myth and indeed in all narrative. Emerging at a unique historical moment when the traditional values of an oral culture are increasingly subjected to the critical spirit fostered by literacy and 
when the relatively secure hierarchies of the archaic world order are tested and reexamined, tragedy experiments with the reversal or violent interweaving of the codes of the social order and deconstructs the system to show the hidden logic of its workings. It can even represent the zero-degree of signification, when the relations are so densely interwoven, the description so thick (to use Clifford Geertz's term) ${ }^{41}$ that signification itself is called into question, as in the scene of Cassandra's prophecy in the Agamemnon (I072-I I 77). Unlike more static cultures, the Greeks of the classical period were able to incorporate into their narrative systems this process of reflexivity and its ambiguous potential for negating the logic of those narrative systems. It is one of the most remarkable qualities of the megatext of the mythical narratives that it could expand to assimilate its own negations and reversals.

Tragedy stands at the intersection of two opposing relations to its mythical material: the further expansion of the mythic megatext as it generates fresh narratives from the old matrices and the continual questioning, analyzing, and even negating of the mythical models. This elasticity of the myths is perhaps latent in the dynamic potential of the system from the beginning, that quality which could generate the kind of paradigmatic relation so characteristic of Greek mythic literature from its earliest times.

For this metalingual and metaliterary functioning of myth in tragedy, structural and semiotic analysis has much to contribute. It can reveal the interlocking of relations in the symbolic systems formed by the myths. It can also help analyze the clash of value systems, the functioning of the sign systems, and particularly those metaliterary levels where the text calls attention to its own fragility and artificiality as a construct of signs and symbols. Tragedy is a form of mythical narrative which makes overt its own deliberateness as a device of the human intellect to keep out chaos or, in other terms, to resist entropy and its symbolic equivalent in language: disorder, incoherence, unintelligibility, nonmeaning, meaninglessness. It thereby reinscribes that potential disorder and chaos into the structured nature of human life with that safe danger whose paradox is the paradox of tragedy.

4I. T. Clifford Geertz, "Thick Description: Toward an Interpretive Theory of Culture," in his The Interpretation of Culture (New York I973) 3-30; also "Deep Play: Notes on the Balinese Cockfight," in the same volume, 4I2-53. 